\title{
Successful treatment of severe COVID-19 pneumonia with tocilizumab: A series of three cases
}

\author{
Joanna Chochol-Labun ${ }^{1}$, Renata Wachnicka-Truty ${ }^{1}$, Małgorzata Sinica-Latecka ${ }^{1}$, \\ Katarzyna Sikorska ${ }^{2}$, Marek Koziński ${ }^{1}$ \\ ${ }^{1}$ Department of Cardiology and Internal Diseases, Institute of Maritime and Tropical Medicine, \\ Medical University of Gdansk, Gdynia, Poland \\ ${ }^{2}$ Department of Tropical and Parasitic Diseases, Institute of Maritime and Tropical Medicine, \\ Medical University of Gdansk, Gdynia, Poland
}

Severe coronavirus disease 2019 (COVID-19) pneumonia associated with cytokine storm remains a challenge for clinicians. It is usually complicated by multiple organ dysfunction and despite optimal contemporary therapy leads to high mortality.

In this research letter, we present 3 consecutive patients with severe COVID-19 pneumonia who between January and March 2021 were successfully treated with tocilizumab (a humanized antibody to the soluble interleukin-6 [IL-6] receptor) added to the standard therapy. This treatment was approved by the local ethics committee and subsequently all patients provided an informed written consent. On admission, all patients were moderately/severely ill with predominant respiratory failure and markedly elevated C-reactive protein (CRP) concentration (Table 1). Therapy with tocilizumab was initiated on day 1 in 2 patients and on day 6 in the $3^{\text {rd }}$ one when he developed respiratory collapse requiring high flow oxygen therapy. All patients received two doses of tocilizumab and then their CRP concentration dropped on average by $71 \%$. Following administration of tocilizumab combined with best known therapy, all patients were slowly and continuously improving. They all were discharged home in a relatively good condition and at a short-term follow-up are mildly symptomatic or asymptomatic.

The decision to use tocilizumab was based on the promising results of randomized clinical trials (RCTs) published since March 2020 [1-10]. The largest and most recent study with the most spectacular outcomes is the RECOVERY trial [1]. When we treated our patients its results have only been published as a preprint. This trial included 4,116 participants receiving invasive ventilation (14\%), non-invasive ventilation $(41 \%)$ or usual oxygen therapy (45\%). All enrolled patients had oxygen saturation $<92 \%$ and CRP concentration $>75 \mathrm{mg} / \mathrm{dL}$. Median CRP in the RECOVERY trial was 143 [interquartile range $107-204] \mathrm{mg} / \mathrm{L}$ which is similar to our patients. Additionally, $82 \%$ of patients in the REVOVERY trial received systemic corticosteroids at randomization. The primary endpoint (all-cause 28-day mortality) was substantially reduced in the tocilizumab on top of standard care vs. standard care alone group ( $29 \%$ vs. $33 \%, p=0.007)$, with consistent results in all predefined subgroups. Significant reductions in terms of secondary endpoints were also achieved in tocilizumab-treated patients (discharge from hospital alive within 28 days [ $54 \%$ vs. $47 \%$ ], composite outcome of invasive mechanical ventilation or death [33\% vs. 38\%] and use of hemodialysis or hemofiltration [5\% vs $7 \%$ ]). Tocilizumab benefits were observed regardless of the level of respiratory support and were additional to the benefits of systemic corticosteroids, another class of anti-inflammatory agents. Also, the results of two moderate size RCTs indicated clinical benefits of tocilizumab. In the REMAPCAP trial conducted in critically ill patients with COVID-19 pneumonia receiving organ support in

Address for correspondence: Prof. Marek Koziński, MD, PhD, FESC, Department of Cardiology and Internal Diseases, Institute of Maritime and Tropical Medicine, Medical University of Gdansk, ul. Powstania Styczniowego 9B, 81-519 Gdynia, Poland, tel: +4858 69984 06, e-mail: marek.kozinski@gumed.edu.pl

Received: 6.04.2021 Accepted: $10.10 .2021 \quad$ Early publication date: 27.10.2021

This article is available in open access under Creative Common Attribution-Non-Commercial-No Derivatives 4.0 International (CC BY-NC-ND 4.0) license, allowing to download articles and share them with others as long as they credit the authors and the publisher, but without permission to change them in any way or use them commercially. 
Table 1. Characteristics of patients with severe COVID-19 pneumonia and respiratory failure treated with tocilizumab.

\begin{tabular}{|c|c|c|c|}
\hline & Patient 1 & Patient 2 & Patient 3 \\
\hline \multicolumn{4}{|l|}{ Demographic data } \\
\hline Age [years] & 61 & 61 & 70 \\
\hline Gender & Male & Female & Male \\
\hline \multicolumn{4}{|c|}{ Clinical characteristics and course, including respiratory status and support } \\
\hline Body mass index $\left[\mathrm{kg} / \mathrm{m}^{2}\right]$ & 25 & 34 & 27 \\
\hline Comorbidities & $\begin{array}{l}\text { Bronchial asthma, acute } \\
\text { kidney injury (stage } 1 \\
\text { according to KDIGO) }\end{array}$ & $\begin{array}{l}\text { Hypertension, paroxysmal } \\
\text { atrial fibrillation, history of } \\
\text { pulmonary embolism, } \\
\text { bronchial asthma, status } \\
\text { post colon cancer surgery }\end{array}$ & $\begin{array}{l}\text { Type } 2 \text { diabetes mellitus, } \\
\text { diabetic neuropathy }\end{array}$ \\
\hline $\begin{array}{l}\text { Duration of symptom onset } \\
\text { to hospital admission [days] }\end{array}$ & 7 & 7 & 12 \\
\hline $\begin{array}{l}\text { Clinical status on } 7 \text { level } \\
\text { ordinal scale on hospital } \\
\text { admission }\end{array}$ & 4 & 4 & 4 \\
\hline $\begin{array}{l}\text { Extent of the involved lung } \\
\text { tissue on } \mathrm{CT}[\%]\end{array}$ & $27^{*}$ & 78 & 75 \\
\hline $\begin{array}{l}\text { Oxygen saturation on } \\
\text { admission }[\%]\end{array}$ & $\begin{array}{l}90 \text { then deterioration } \\
\text { to } 75 \text { on day } 3\end{array}$ & 80 & 70 \\
\hline Minimal arterial $\mathrm{pO}_{2}[\mathrm{mmHg}]$ & 49.5 & 45.1 & 50.3 \\
\hline Respiratory support & $\begin{array}{c}\text { High flow oxygen through } \\
\text { a nasal cannula } \\
\text { [up to } 60 \mathrm{~L} / \mathrm{min} \text { through } \\
16 \text { days] }\end{array}$ & $\begin{array}{c}\text { Supplemental oxygen } \\
\text { through a face mask } \\
\text { [up to } 17 \mathrm{~L} / \mathrm{min} \text { through } \\
11 \text { days] }\end{array}$ & $\begin{array}{c}\text { Supplemental oxygen } \\
\text { through a face mask } \\
\text { [up to } 17 \mathrm{~L} / \mathrm{min} \text { through } \\
10 \text { days] }\end{array}$ \\
\hline Blood culture & \multicolumn{3}{|c|}{ All negative (obtained twice in all patients) } \\
\hline \multicolumn{4}{|c|}{ Laboratory measurements on hospital admission } \\
\hline Lymphocyte count [G/L] & 0.35 & 0.75 & 0.95 \\
\hline CRP concentration [mg/L] & 137.1 & 209.7 & 169 \\
\hline $\begin{array}{l}\text { Procalcitonin concentration } \\
{[\mathrm{ng} / \mathrm{mL}]}\end{array}$ & 0.28 & 0.2 & 0.22 \\
\hline $\begin{array}{l}\text { D-dimer concentration } \\
\text { [ng/mL] }\end{array}$ & 35200 & 768 & Not available \\
\hline $\begin{array}{l}\text { Creatinine concentration } \\
{[\mathrm{mg} / \mathrm{dL}]}\end{array}$ & $\begin{array}{c}1.44 \text { (after patient hydration } \\
\text { a decrease to } 0.83 \text { ) }\end{array}$ & 0.94 & 0.94 \\
\hline $\begin{array}{l}\text { Lactate dehydrogenase } \\
\text { activity [U/L] }\end{array}$ & 720 & 454 & Not available \\
\hline Cardiac troponin $\mathrm{T}$ & Negative & Mildly elevated (0.055 ng/L) & Negative \\
\hline \multicolumn{4}{|c|}{ Pharmacotherapy during hospitalization } \\
\hline $\begin{array}{l}\text { Treatment with } \\
\text { dexamethasone }\end{array}$ & $\begin{array}{c}\text { Yes } \\
\text { (6 mg IV once daily) }\end{array}$ & $\begin{array}{c}\text { Yes } \\
\text { (6 mg IV once daily) }\end{array}$ & $\begin{array}{c}\text { Yes } \\
\text { (6 mg IV once daily) }\end{array}$ \\
\hline $\begin{array}{l}\text { Treatment with } \\
\text { remdesivir }\end{array}$ & $\begin{array}{c}\text { Yes } \\
\text { (initiated on day 3) }\end{array}$ & $\begin{array}{c}\text { Yes } \\
\text { (initiated on day 3) }\end{array}$ & $\begin{array}{c}\text { Yes } \\
\text { (initiated on day 1) }\end{array}$ \\
\hline Anticoagulation & $\begin{array}{l}\text { Prophylactic dose } \\
\text { of enoxaparin }\end{array}$ & Rivaroxaban 20 mg/day & $\begin{array}{l}\text { Prophylactic dose } \\
\text { of enoxaparin }\end{array}$ \\
\hline Treatment with tocilizumab & $\begin{array}{l}\text { Initiated on day } 6 \text { at the } \\
\text { dose of } 600 \mathrm{mg} \text { IV which } \\
\text { was repeated on day } 7\end{array}$ & $\begin{array}{l}\text { Initiated on day } 1 \text { at the } \\
\text { dose of } 720 \mathrm{mg} \text { IV which } \\
\text { was repeated on day } 2\end{array}$ & $\begin{array}{l}\text { Initiated on day } 2 \text { at the } \\
\text { dose of } 640 \mathrm{mg} \text { IV which } \\
\text { was repeated on day } 3\end{array}$ \\
\hline $\begin{array}{l}\text { Effect of tocilizumab } \\
\text { administration on CRP } \\
\text { concentration }\end{array}$ & $\begin{array}{l}\text { After } 2^{\text {nd }} \text { dose a decrease } \\
\text { from } 137 \text { to } 56 \mathrm{mg} / \mathrm{L} \\
\text { on the } 2^{\text {nd }} \text { day }\end{array}$ & $\begin{array}{l}\text { After } 2^{\text {nd }} \text { dose a decrease } \\
\text { from } 209 \text { to } 40 \mathrm{mg} / \mathrm{L} \\
\text { on the } 3^{\text {rd }} \text { day }\end{array}$ & $\begin{array}{c}\text { After } 2^{\text {nd }} \text { dose a decrease } \\
\text { from } 169 \text { to } 58 \mathrm{mg} / \mathrm{L} \\
\text { on the } 3^{\text {rd }} \text { day }\end{array}$ \\
\hline
\end{tabular}


Table 1 (cont.). Characteristics of patients with severe COVID-19 pneumonia and respiratory failure treated with tocilizumab.

\begin{tabular}{|c|c|c|c|}
\hline & Patient 1 & Patient 2 & Patient 3 \\
\hline Antibiotic therapy & $\begin{array}{l}\text { Ceftriaxone initiated on } \\
\text { admission then on day } 2 \\
\text { changed for piperacillin/ } \\
\text { /tazobactam then on day } 8 \\
\text { changed for meropenem } \\
\text { for } 7 \text { days }\end{array}$ & $\begin{array}{l}\text { Ceftriaxone initiated on } \\
\text { admission and continued } \\
\text { for } 10 \text { days }\end{array}$ & $\begin{array}{l}\text { Ceftriaxone initiated on } \\
\text { admission and continued } \\
\text { for } 10 \text { days }\end{array}$ \\
\hline \multicolumn{4}{|c|}{ Hospital discharge and follow-up } \\
\hline $\begin{array}{l}\text { Length of hospitalization } \\
\text { [days] }\end{array}$ & 28 & 13 & 14 \\
\hline $\begin{array}{l}\text { Clinical status at the end } \\
\text { of hospitalization }\end{array}$ & \multicolumn{3}{|c|}{$\begin{array}{c}\text { Discharged in a relatively good condition with the need of temporal low } \\
\text { flow oxygen supplementation at home }\end{array}$} \\
\hline Length of follow-up [days] & 53 & 26 & 31 \\
\hline $\begin{array}{l}\text { Clinical status at the end } \\
\text { of follow-up }\end{array}$ & $\begin{array}{l}\text { Fully recovered without } \\
\text { any respiratory failure }\end{array}$ & \multicolumn{2}{|c|}{$\begin{array}{c}\text { The need of temporary low flow oxygen } \\
\text { supplementation at home }\end{array}$} \\
\hline
\end{tabular}

*No control CT was performed after deterioration of the respiratory status as the patients was treated with high flow oxygen therapy and we were not able to transport him safely without tracheal intubation; CRP - C-reactive protein; CT — computed tomography; KDIGO — Kidney Disease: Improving Outcomes; $\mathrm{pO}_{2}$ - partial pressure of oxygen; $\mathrm{SpO}_{2}$ - oxygen saturation

intensive care units, treatment with the IL-6 receptor antagonist (tocilizumab $[\mathrm{n}=353]$ or sarilumab $[\mathrm{n}=48]$ ) when compared with the control group $(\mathrm{n}=402)$ improved clinical outcomes, including 90-day survival [2]. Similarly, the EMPACTA trial demonstrated superiority of tocilizumab $(n=249)$ over placebo $(n=128)$ on the primary composite endpoint of mechanical ventilation or death by day 28 , but without any improvement in mortality [3]. This study included only patients who did not require mechanical ventilation at randomization. Importantly, several small/moderate size (all largely underpowered for assessment of hard clinical endpoints) RCTs indicated a neutral effect of tocilizumab on clinical outcomes [4-7], with some minor benefits seen in the CORIMUNO-19 study [5]. On the other hand, the TOCIBRAS trial was stopped early after inclusion of 129 participants due to a signal of increased mortality at 15 days related to tocilizumab therapy $(11 / 65$ [17\%] vs. $2 / 64$ [3\%]) [8]. This finding may be simply due to chance, considering the very low mortality in the standard care alone group. In all of the RCTs discussed above, adverse events were not more frequent in the tocilizumab vs. placebo/standard care group [1-8]. Finally, an updated meta-analysis of all available RCTs performed by the ROCOVERY investigators shows all-cause mortality benefit in patients hospitalized for COVID-19 pneumonia and treated with tocilizumab added to usual care when compared with the usual care alone group (relative risk 0.87 ; $95 \%$ confidence interval $0.79-0.96$; $p=0.005$ ), with a substantial heterogeneity among the included trials [1]. Furthermore, it is suggested that tocilizumab may exert an additive beneficial effect in remdesivir-treated patients [9], as was used in the present case series.

Based on the totality of the research evidence [10] and our clinical experience, we believe that tocilizumab is well tolerated and may be beneficial on top of standard therapy if early initiated in patients with COVID-19 pneumonia and both enhanced inflammatory response and a large extent of the involved lung tissue. However, further RCTs are necessary to define best tocilizumab responders.

\section{Conflict of interest: None declared}

\section{References}

1. Abani O, Abbas A, Abbas F, et al. RECOVERY Collaborative Group. Tocilizumab in patients admitted to hospital with COVID-19 (RECOVERY): a randomised, controlled, open-label, platform trial. Lancet. 2021; 397(10285): 1637-1645, doi: 10.1016/ s0140-6736(21)00676-0, indexed in Pubmed: 33933206.

2. Gordon AC, Mouncey PR, Al-Beidh F, et al. Interleukin-6 receptor antagonists in critically ill patients with Covid-19. N Engl J Med. 2021; 384(16): 1491-1502, doi: 10.1056/NEJMoa2100433, indexed in Pubmed: 33631065.

3. Salama C, Han J, Yau L, et al. Tocilizumab in patients hospitalized with Covid-19 pneumonia. N Engl J Med. 2021; 384(1): 20-30, doi: 10.1056/NEJMoa2030340, indexed in Pubmed: 33332779.

4. Stone JH, Frigault MJ, Serling-Boyd NJ, et al. Efficacy of tocilizumab in patients hospitalized with Covid-19. N Engl J Med. 2020; 383(24): 2333-2344, doi: 10.1056/NEJMoa2028836, indexed in Pubmed: 33085857. 
5. Hermine O, Mariette X, Tharaux PL, et al. Effect of tocilizumab vs usual care in adults hospitalized with COVID-19 and moderate or severe pneumonia: a randomized clinical trial. JAMA Intern Med. 2021; 181(1): 32-40, doi: 10.1001/jamainternmed.2020.6820, indexed in Pubmed: 33080017.

6. Rosas IO, Bräu N, Waters M, et al. Tocilizumab in hospitalized patients with severe Covid-19 pneumonia. N Engl J Med. 2021; 384(16): 1503-1516, doi: 10.1056/NEJMoa2028700, indexed in Pubmed: 33631066.

7. Salvarani C, Dolci G, Massari M, et al. Effect of tocilizumab vs standard care on clinical worsening in patients hospitalized with COVID-19 pneumonia: a randomized clinical trial. JAMA Intern Med. 2021; 181(1): 24-31, doi: 10.1001/jamainternmed.2020.6615, indexed in Pubmed: 33080005.
8. Veiga VC, Prats JA, Farias DLC, et al. Effect of tocilizumab on clinical outcomes at 15 days in patients with severe or critical coronavirus disease 2019: randomised controlled trial. BMJ. 2021; 372: n84, doi: 10.1136/bmj.n84, indexed in Pubmed: 33472855 .

9. Akinosoglou K, Velissaris D, Ziazias D, et al. Remdesivir and tocilizumab: Mix or match. J Med Virol. 2021; 93(1): 56-58, doi: 10.1002/jmv.26117, indexed in Pubmed: 32492200.

10. Ghosn L, Chaimani A, Evrenoglou T, et al. Interleukin-6 blocking agents for treating COVID-19: a living systematic review. Cochrane Database Syst Rev. 2021; 3: CD013881, doi: 10.1002/14651858.CD013881, indexed in Pubmed: 33734435 . 